Reviu Akuntansi dan Bisnis Indonesia, Vol. 2 No. 2, Hlm: 116-128, Desember 2018

Website: http://journal.umy.ac.id/index.php/rab

\title{
Menuju Terbentuknya PSAK (Pernyataan Standar Akuntansi Keuangan) Wakaf di Indonesia
}

\author{
Mevita Yollanda; M Akhyar Adnan \\ Program Studi Akuntansi Univeritas Muhammadiyah Yogyakarta.
}

\section{N F O A R T I K E L}

Kata Kunci:

Lembaga Wakaf,

Akuntansi, Standar

Akuntansi Keuangan,

Dewan Wakaf Indonesia

Jenis Artikel:

Penelitian Empiris

Correspondence:

adnan@umy.ac.id

\author{
A B S T R A K
}

Perkembangan awqaf sebagai salah satu filantropi ekonomi dalam beberapa tahun sangat pesat. Apalagi dengan tumbuhnya wakaf tunai dan penerimaan aset wakaf. Namun belum ada standar akuntansi keuangan untuk dapat mengakomodasi pelaporan keuangan wakaf sampai sekarang. Lembaga awqaf umumnya mengacu pada standar akuntansi dan dianggap relevan seperti SAP dan PSAK 45. Pada tahun 2016 BWI menerbitkan buku yang disebut "Buku Pedoman Akuntansi Wakaf", namun buku ini tidak dapat digunakan untuk semua lembaga awqaf di Indonesia. Oleh karena itu penelitian ini bertujuan untuk mendorong pengembangan standar akuntansi keuangan untuk wakaf. Karena pedoman ini belum menjadi standar akuntansi yang dapat digunakan oleh semua lembaga awqaf di Indonesia. Penelitian ini menggunakan model pendekatan kualitatif dengan analisis isi metode penelitian. Hasil dari penelitian ini adalah PSAK Wakaf sangat dibutuhkan. Penelitian ini memberikan beberapa pemikiran mengenai ruang lingkup PSAK Wakaf dan penyusunan standar akuntansi keuangan proposal wakaf dalam bentuk ilustrasi laporan keuangan seperti laporan posisi keuangan, laporan arus kas, laporan perubahan dana, laporan perubahan dana sumber daya, dan laporan kegiatan keuangan.

(C) 2019 RAB. Published by Universitas Muhammadiyah Yogyakarta

\section{PENDAHULUAN}

Wakaf merupakan salah satu filantropi ekonomi Islam yang mampu menyediakan kebutuhan barang publik sebagai kemashlahatan umat. Perkembangan harta wakaf di Indonesia sangat cepat. Berdasarkan data Kementerian Agama dari tahun ke tahun bahkan dari bulan ke bulan harta wakaf yang diterima semakin meningkat. Selain pertambahan harta wakaf, wakaf uang pun juga meningkat. Hal ini ditunjukkan dengan semakin banyaknya lembaga keuangan yang menjadi nazhir wakaf uang di Indonesia. Hingga Oktober 2017 jumlah nazhir wakaf uang yang terdaftar di Badan Wakaf Indonesia berjumlah 187 lembaga.

Sebagai lembaga wakaf yang merupakan lembaga keuangan Syariah pastinya harus memiliki akuntabilitas. Akuntabilitas ditunjukkan sebagai bentuk pertanggungjawaban lembaga wakaf Setiabudi dan Triyuwono (2002) menyatakan bahwa accountability merupakan pertanggungjawaban setiap orang atas segala tindakannya serta implikasinya untuk kehidupan dunia dan akhirat. Sehingga setiap orang tidak dapat bertindak tanpa pertanggungjawaban atas segala apa yang dipercayakan kepadanya.

Penelitian sebelumnya mengenai akuntabilitas lembaga wakaf menunjukkan bahwa jika lembaga wakaf menerapkan prinsip akuntabilitas, maka kepercayaan publik terhadap lembaga wakaf meningkat. Secara operasional akuntabilitas ditunjukkan dengan pembuatan laporan 
keuangan (reporting), tindakan cepat tanggap (responding), dan adanya pelibatan (involving). Oleh karena itu, akuntabilitas sangat penting bagi legimitasi lembaga wakaf (Budiman, 2011).

Tabel 1 Lokasi tanah wakaf di Indonesia

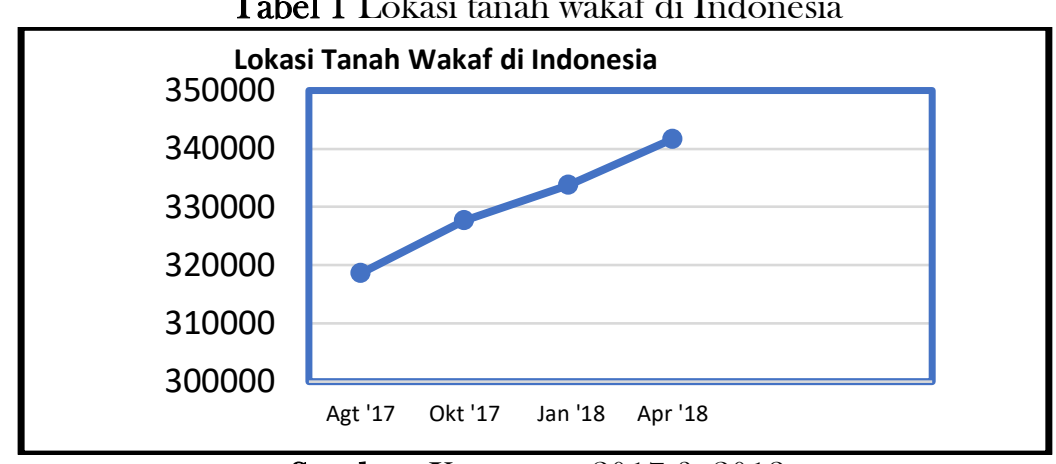

Sumber: Kemenag, 2017 \& 2018

Tabel 2 Nazhir Wakaf Uang

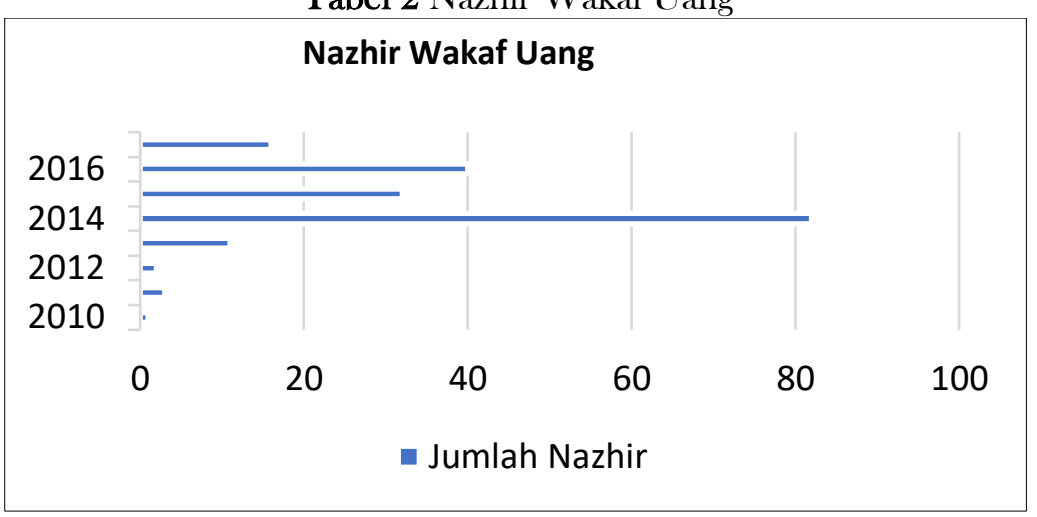

Sumber: Badan Wakaf Indonesia, 2018

Menurut Suparman dan Nizar (2009), Badan Wakaf Indonesia telah menyiapkan rancangan laporan keuangan, berupa buku pedoman akuntansi wakaf. Berdasarkan wawancara dengan Nizar selaku Akuntan BWI beliau mengungkapkan bahwa pembuatan buku tersebut berdasarkan kesepakatan bersama melalui Divisi Pembinaan nazhir BWI, dengan berpedoman pada SAK EMKM (Standar Akuntansi Keuangan Entitas Mikro, Kecil, dan Menengah). Namun, buku tersebut belum bisa menjadi standar akuntansi untuk Lembaga Wakaf di Indonesia. Hal ini dikarenakan pihak atau lembaga yang berwenang membuat dan mengesahkan suatu standar akuntansi di Indonesia adalah IAI (Ikatan Akuntan Indonesia). Oleh karena itu, saat ini sangat diperlukan kerangka konseptual dan standar akuntansi keuangan untuk Lembaga Wakaf. Karena tanpa adanya konsep dasar dan standar akuntansi keuangan, maka perbaikan dan pemberdayaan lembaga wakaf akan sia-sia (Ihsan, Sulaiman, Alwi, dan Adnan, 2007).

Untuk menyusun standar akuntansi keuangan wakaf terdapat beberapa standar akuntansi keuangan yang dapat digunakan sebagai referensi seperti AAOIFI (Accounting \& Auditing Organization for Islamic Financial Institution) yaitu Shari'a Standards 33 Waqf dan FAS (Financial Accounting Statement) 1 General Presentation and Disclosure in the Financial Statements of Islamic Banks and Financial Institutions, SORP (Statement of Recommended Practice) 2015, dan Buku Pedoman Akuntansi Wakaf dari Badan Wakaf Indonesia. Menurut Adnan, Sulaiman, dan Nor (2007) menyebutkan bahwa baik konsep dan standar dari AAOIFI maupun dari SORP 2015 dapat diadopsi di Indonesia. Maka, dapat disimpulkan bahwa ketiga aturan tersebut dapat digunakan sebagai referensi dalam pembentukan standar akuntansi keuangan untuk Lembaga Wakaf di Indonesia. Namun, perlu dikembangkan lagi manakah yang lebih cocok untuk Lembaga Wakaf yang ada di Indonesia. 
Adanya pembentukan standar akuntansi keuangan wakaf, akan berimplikasi menjadi sebuah perwujudan akuntabilitas dari Lembaga Wakaf. Dimana dengan adanya akuntabilitas atau pertanggungjawaban Lembaga Wakaf berupa laporan keuangan, akan menguatkan legitimasi sosial yaitu kepercayaan masyarakat sehingga akan meningkatkan dukungan masyarakat untuk pengelolaan wakaf (Budiman, 2011). Oleh karena itu, dalam penyusunan standar akuntansi keuangan harus ada beberapa hal seperti definisi, pengakuan, pengukuran, penyajian, dan pengungkapan. Beberapa hal tersebutlah yang nantinya dapat menjadi sebuah standar akuntansi keuangan yang dapat menyeragamkan laporan keuangan wakaf.

Berdasarkan uraian diatas, maka penulis tertarik melakukan penelitian mengenai standar akuntansi keuangan untuk lembaga wakaf dikarenakan sangat diperlukannya sebagai pedoman pelaporan keuangan wakaf bagi nazhir. Penelitian ini merupakan penelitian yang baru. Berdasarkan latar belakang tersebut maka penulis akan melakukan penelitian dengan judul "Menuju Terbentuknya PSAK (Pernyataan Standar Akuntansi Keuangan) Wakaf di Indonesia"

\section{TINJAUAN LITERATUR DAN PERUMUSAN HIPOTESIS}

\section{Teori Stewardship}

Teori Stewardship merupakan teori yang membahas mengenai hubungan agen dan principal. Dimana yang menjadi agen adalah manajer, sedangkan yang menjadi principal adalah pemilik. Teori ini mengasumsikan bahwa hubungan antara agen dan principal selaras, bahwa agen bertindak untuk kepentingan bersama dan sesuai dengan tujuan dari pemilik (Raharjo, 2007). Oleh karena itu, untuk memaksimalkan tujuan pemilik maka agen perlu menerapkan konsep yaitu Good Corporate Governance.

Adanya Corporate Governance dapat membantu perusahaan atau entitas agar lebih sehat yaitu agen sebagai manajemen dapat bertanggung jawab mengoptimalkan keuntungan pemilik atau perusahaan. Komite Nasional Kebijakan Governance (KNKG) tahun 2006 mendefinisikan lima prinsip utama penting yang ada dalam corporate governance yaitu: transparansi, akuntanbilitas, responbilitas, independensi, dan kewajaran dan kesetaraan. Berdasarkan hal tersebut nazhir selaku pengelola lembaga wakaf semestinya bertanggung jawab untuk memaksimalkan keuntungan dari harta wakaf agar manfaatnya dapat terus tersalurkan, sebagai bentuk pertanggungjawaban terhadap wakif. Oleh karena itu, sebagai bentuk pertanggungjawaban nazhir harus membuat laporan keuangan. Untuk menyusun dan menyajikan laporan keuangan tersebut pastinya suatu perusahaan atau entitas memerlukan suatu pedoman yang dapat digunakan secara umum.

\section{Pengertian Wakaf}

Wakaf berasal dari bahasa Arab yaitu "waqafa" yang artinya "menahan" atau "diam ditempat". Secara syariah, wakaf berarti menahan harta dan memberikan manfaat di jalan Allah. (Sabiq dalam Nurhayati, dan Wasilah, 2015). Wakaf menjadi sebuah filantropi dalam Islam sebagai pengembang sosial-ekonomi bagi kesejahteraan umat.

\section{Gambaran Umum Lembaga Wakaf}

Lembaga wakaf atau nazhir merupakan suatu organisasi yang dibentuk sebagai wadah penerima harta wakaf dari wakif dan bertugas mengelola harta tersebut. Lembaga ini selain bergerak disektor sosial juga bergerak pada sektor komersial. Pada sektor sosial atau non-profit, harta wakaf yang diterima dikelola untuk membangun masjid dan mushola, serta rumah sakit dan sekolah gratis bagi yang membutuhkan. Saat ini sebagian telah dikembangkan menjadi lebih produktif dan profesional, misalnya dengan penambahan fasilitas gedung pertemuan, toko atau mini market, gedung pernikahan. Untuk sektor komersial atau profit, harta wakaf yang diterima digunakan untuk 
investasi. Pemberdayaan wakaf pada sektor ini disalurkan, salah satunya dengan akad mudharabah atau akad investasi lain disektor keuangan syariah.

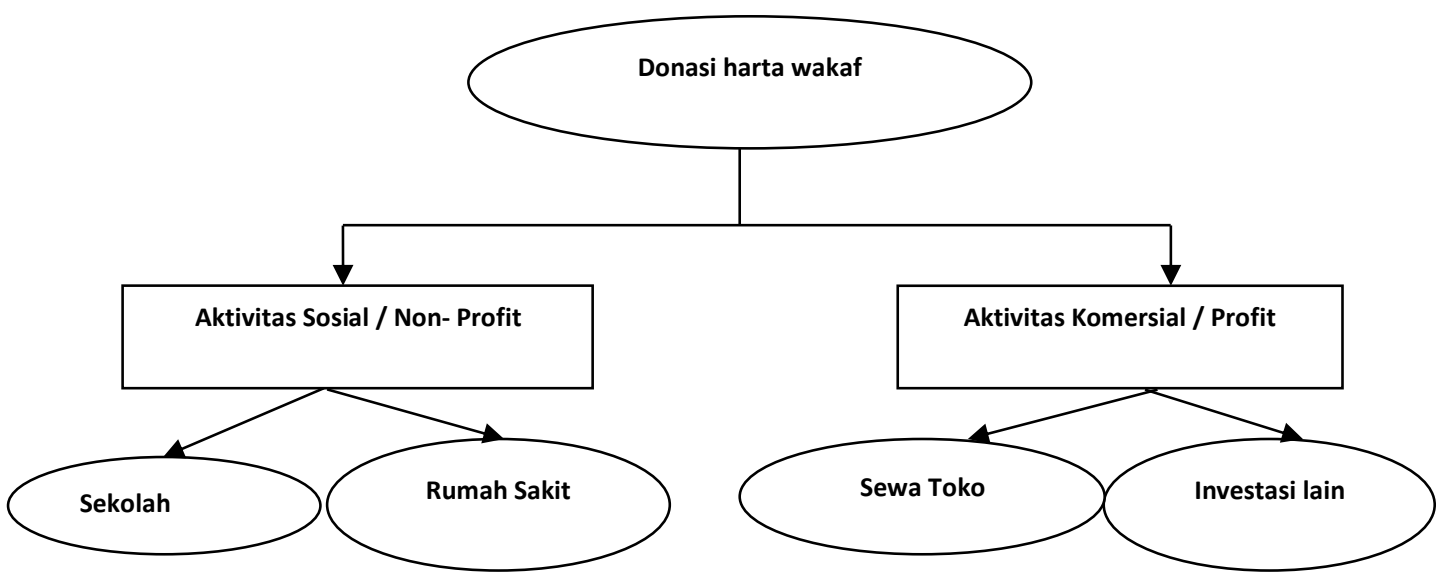

Gambar 1 Gambaran Umum Lembaga Wakaf

Sumber: Adnan, Sulaiman, dan Nor, 2007

\section{Pelaporan Keuangan}

Tujuan pelaporan keuangan adalah untuk menentukan bentuk, isi, jenis, dan susunan laporan keuangan. Tujuan pelaporan keuangan harus diidentifikasi dengan jelas, sehingga informasi yang dihasilkan dapat memuaskan pihak yang dituju dan pengguna laporan keuangan lainnya (Suwardjono, 2014). Tujuan pelaporan keuangan ini harus diselaraskan dengan prinsip dari akuntansi Syariah, yaitu seperti yang terdapat didalam Surah Al-Baqarah: 282. Prinsip-prinsip tersebut adalah prinsip pertanggungjawaban, prinsip keadilan, dan prinsip kebenaran. Dimana pada prinsip pertanggungjawaban didefinisikan bahwa setiap individu yang melakukan praktik bisnis harus mempertanggungjawabkan segala aktivitasnya yaitu dengan membuat laporan keuangan. Pertanggungjawaban ini pun tidak hanya kepada sesama manusia tetapi juga kepada Allah SWT pastinya, seperti yang tertuang di dalam Al-quran yaitu Q.S 2:212; 3:27; 3:37; 13:18; 13:40;24:38; 38:39; 69:62 (AC, 2001 4). Menurut PABU suatu objek yang harus dilaporkan, berdasarkan pedoman sebaiknya memenuhi beberapa hal yaitu definisi, pengukuran/penilaian, pengakuan, penyajian, dan pengungkapan (Suwardjono, 2014).

Pelaporan akuntansi syariah harus berdasarkan Kerangka Dasar Penyusunan dan Penyajian Laporan Keuangan Syariah (KDPPLK Syariah) yang merupakan konsep yang mendasari penyusunan dan penyajian laporan keuangan transaksi syariah. Berbeda dengan akuntansi konvensional, akuntansi syariah memiliki konsep dasar paradigma, asas transaksi syariah, dan karakteristik transaksi syariah. Asas transaksi syariah harus memenuhi lima prinsip yaitu persaudaraan (ukhuwah), keadilan ('adalah), kemashlahatan (maslahah), keseimbangan (tawazun), dan universalisme (syumuliyah), sedangkan untuk karakteristik dari transaksi syariah yaitu tidak boleh mengandung unsur riba, kezaliman, maysir, gharar, dan haram.

Berdasarkan PSAK 101 tentang Penyajian Laporan Keuangan Syariah, struktur dan isi pelaporan syariah terdiri atas delapan laporan keuangan. Oleh karena itu, kemungkinan nanti standar akuntansi wakaf yang terbentuk memenuhi beberapa macam laporan keuangan dari kedelapan laporan keuangan tersebut. Agar informasi yang tersaji dapat memenuhi kebutuhan informasi pengguna laporan keuangan. Pengguna laporan keuangan dari lembaga wakaf antara lain adalah wakif (orang yang mewakafkan hartanya), pemerintah, investor, dan masyarakat. 


\section{METODE PENELITIAN}

Penelitian ini menggunakan model penelitian pendekatan kualitatif. Penelitian kualitatif adalah penelitian dimana peneliti menjadi instrumen kunci dalam penelitian tersebut (Sugiyono, 2005). Metode penelitian yang digunakan penulis yaitu content analysis. Analisis isi (content analysis) merupakan metode penelitian yang digunakan untuk menghasilkan suatu kesimpulan atau keputusan dari berbagai dokumen tertulis dengan mengidentifikasi secara objektif dan sistematis suatu data atau informasi (Yusuf, 2015).

Objek penelitian dalam penelitian ini adalah lembaga wakaf. Sedangkan subjek penelitian ini yaitu standar akuntansi keuangan untuk lembaga wakaf. Narasumber penelitian ini adalah pakar ekonomi Islam, akademisi, praktisi di lembaga wakaf, nazhir dan wakif. Jenis data yang digunakan di dalam penelitian ini yaitu data primer dan data sekunder. Data primer penelitian ini adalah data yang berasal dari wawancara dengan pakar ekonomi Islam yang mengkaji tentang wakaf, akademisi, wakif, nazhir dan praktisi di lembaga wakaf. Data sekunder yang digunakan antara lain Buku Pedoman Akuntansi Wakaf dari Badan Wakaf Indonesia, SORP 2015 dan AAOIFI, serta bukubuku tentang wakaf.

Teknik pengumpulan data di dalam penelitian ini adalah wawancara, dokumen, dan studi literature. Sedangkan metode analisis yang digunakan di dalam penelitian ini adalah Model Miles dan Huberman (Sugiyono, 2014). Model ini memiliki tiga tahapan analisis yaitu reduksi data, penyajian data, dan penarikan kesimpulan.

\section{HASIL DAN PEMBAHASAN}

\section{Profil Narasumber}

Tabel 3 Profil Narasumber

\begin{tabular}{|c|c|c|c|}
\hline No & Narasumber & Jabatan & Pendapat \\
\hline 1 & $\begin{array}{l}\text { Hendri Tanjung, MM., } \\
\text { M.Ag., M.Phil., Ph.D. }\end{array}$ & $\begin{array}{l}\text { Anggota Badan Wakaf } \\
\text { Indonesia Pusat }\end{array}$ & Sangat Diperlukan PSAK Wakaf \\
\hline 2 & $\begin{array}{l}\text { Hidayatul Ihsan, M.Sc, } \\
\text { Acc, Ph.D, CA }\end{array}$ & $\begin{array}{l}\text { Pakar Ekonomi Islam } \\
\text { (Wakaf), Anggota Badan } \\
\text { Wakaf Indonesia Perwakilan } \\
\text { Sumatera Barat }\end{array}$ & Sangat Diperlukan PSAK Wakaf \\
\hline 3 & $\begin{array}{l}\text { Drs. Mohammad } \\
\text { Mas'udi, M.Ag. }\end{array}$ & $\begin{array}{l}\text { Anggota Badan Wakaf } \\
\text { Indonesia Perwakilan DIY, } \\
\text { Dosen Fakultas Agama Islam }\end{array}$ & Sangat Diperlukan PSAK \\
\hline 4 & Ahmad Nizar, SE., M.Si & Staf Akuntan & Sangat Diperlukan PSAK Wakaf \\
\hline 5 & Bahrun & Nazhir & Sangat Diperlukan PSAK Wakaf \\
\hline 6 & Suradiyanto & Wakif & Sangat Diperlukan PSAK Wakaf \\
\hline 7 & Sari Mulyanto & Wakif & Sangat Diperlukan PSAK Wakaf \\
\hline 8 & Wintono & Wakif (Salah satu ahli waris) & Tidak diperlukan PSAK Wakaf \\
\hline
\end{tabular}

\section{Urgensi diperlukannya PSAK (Pernyataan Standar Akuntansi Keuangan) Wakaf di Indonesia}

Berdasarkan tabel 4 dapat disimpulkan bahwa saat ini PSAK bagi lembaga wakaf sangat diperlukan. Dengan adanya PSAK Wakaf dapat menggambarkan bagaimana wakaf itu dikelola dengan jelas dan sudah sesuai dengan syariah atau belum. Jika terjadi sesuatu misalnya mengapa harta wakaf itu tidak produktif, maka hal tersebut dapat dilihat di laporan keuangannya. Serta lembaga wakaf juga bisa menghitung bagaimana untuk mempertahankan dari nilai wakaf agar tetap, sama seperti saat diwakafkan oleh wakif. Karena nilai dari harta wakaf itu tidak boleh berkurang. Dan juga dengan adanya PSAK untuk lembaga wakaf, maka karakteristik dari wakaf nantinya dapat terakomodir dengan baik. Menurut Masruki dan Shafii (2013) akuntansi dapat meningkatkan 
praktik lembaga wakaf serta sebagai bentuk akuntabilitas lembaga terhadap wakif. Ihsan menyatakan bahwa:

"Jadi memang mau tidak mau harus ada standar khusus yang mengakomodir karakteristik wakaf yang sangat spesifik dan itu belum ada di standar akuntansi keuangan yang ada di Indonesia pada saat ini."

Kabar baiknya, bahwa saat ini IAI telah membentuk closing group untuk penyusunan standar akuntansi wakaf.

Tabel 4 Pendapat Narasumber Penelitian

\begin{tabular}{|c|c|c|c|}
\hline No. & Nama Narasumber & Jabatan & Organisasi/Lembaga \\
\hline 1 & $\begin{array}{l}\text { Hendri Tanjung, MM., } \\
\text { M.Ag., M.Phil., Ph.D. } \\
\text { (Praktisi) }\end{array}$ & Anggota Badan Wakaf Indonesia Pusat & $\begin{array}{l}\text { Badan Wakaf Indonesia } \\
\text { Pusat }\end{array}$ \\
\hline 2 & $\begin{array}{l}\text { Hidayatul Ihsan, M.Sc, } \\
\text { Acc, Ph.D, CA (Pakar } \\
\text { Ekonomi Wakaf) }\end{array}$ & $\begin{array}{l}\text { Pakar Ekonomi Islam (Wakaf), } \\
\text { Anggota Badan Wakaf Indonesia } \\
\text { Perwakilan Sumatera Barat }\end{array}$ & $\begin{array}{l}\text { Politeknik Negeri Padang, } \\
\text { Badan Wakaf Indonesia } \\
\text { Perwakilan Sumatera Barat }\end{array}$ \\
\hline 3 & $\begin{array}{l}\text { Drs. Mohammad } \\
\text { Mas'udi, M.Ag. } \\
\text { (Akademisi) }\end{array}$ & $\begin{array}{l}\text { Anggota Badan Wakaf Indonesia } \\
\text { Perwakilan DIY, Dosen Fakultas } \\
\text { Agama Islam }\end{array}$ & $\begin{array}{l}\text { Universitas Muhammadiyah } \\
\text { Yogyakarta, Badan Wakaf } \\
\text { Indonesia Perwakilan DIY }\end{array}$ \\
\hline 4. & $\begin{array}{l}\text { Ahmad Nizar, SE., } \\
\text { M.Si }\end{array}$ & Staf Akuntan & $\begin{array}{l}\text { Badan Wakaf Indonesia } \\
\text { Pusat }\end{array}$ \\
\hline 5. & Wintono & Wakif (Salah satu ahli waris) & \\
\hline 6. & Bahrun & Nzhir & PCM Gamping \\
\hline 7. & Suradiyanto & Wakif & - \\
\hline 8. & Sari Mulyanto & Wakif & - \\
\hline
\end{tabular}

Ruang lingkup definisi, pengakuan, pengukuran, penyajian, dan pengungkapan untuk standar akuntansi keuangan wakaf di Indonesia

Untuk terbentuknya suatu standar akuntansi, menurut PABU harus berdasarkan pedoman. Pedoman tersebut harus memenuhi beberapa hal yaitu seperti harus ada definisi dari wakaf, bagaimana pengukurannya, bagaimana pengakuannya, bagaimana penyajian laporan keuangannya, dan hal-hal apa saja yang harus diungkapkan di dalam laporan keuangan seperti definisi, pengukuran/penilaian, pengakuan, penyajian, dan pengungkapan (Suwardjono, 2014). Berikut adalah beberapa hal mengenai ruang lingkup dari PSAK Wakaf.

\section{Definisi}

Ruang lingkup dari definisi PSAK Wakaf nantinya tidak dapat terlepas Undang-Undang No. 41 Tahun 2004 tentang Wakaf dan hukum Fiqih yang melingkupinya. Dengan pertimbangan tersebut maka definisi-definisi yang digunakan diambil dari undang-undang dan hukum Fiqih dengan mengacu pada buku Pedoman Akuntansi Wakaf dari BWI. Berikut adalah uraian dari setiap definisi:

a. "Nazhir adalah pihak yang menerima harta/benda wakaf dari Wakif untuk dikelola dan dikembangkan sesuai dengan peruntukannya."

Definisi tersebut diadopsi dari Undang-Undang No. 41 Tahun 2004 tentang Wakaf pasal 1 ayat 4, dan definisinya pun sama dengan yang ada di buku Pedoman Akuntansi Wakaf dari Badan Wakaf Indonesia

b. "Wakaf adalah perbuatan hukum wakif untuk memisahkan dan/atau menyerahkan sebagian harta benda miliknya untuk dimanfaatkan selamanya atau untuk jangka waktu tertentu sesuai dengan kepentingannya guna keperluan ibadah dan/atau kesejahteraan umum menurut syariah.” 
Begitu pula dengan definisi dari wakaf, penulis adopsi dari undang-undang dan buku Pedoman Akuntansi Wakaf yang berdasarkan pada Undang-Undang No. 41 Tahun 2004 tentang Wakaf pasal 1 ayat 1 .

c. "Harta Benda Wakaf adalah harta benda yang memiliki daya tahan lama dan/atau manfaat jangka panjang serta mempunyai nilai ekonomi menurut syariah yang diwakafkan oleh wakif."

Definisi dari harta benda wakaf ini, penulis adopsi dari undang-undang dan syarat serta rukun sahnya wakaf serta berdasarkan pada Undang-Undang No. 41 Tahun 2004 tentang Wakaf pasal 1 ayat 5. Di buku Pedoman Akuntansi Wakaf tidak ada. Namun, menurut penulis sebaiknya di dalam sebuah pernyataan standar akuntansi keuangan untuk wakaf nantinya, harus ada pendefinisian dari harta atau benda yang dapat diwakafkan oleh wakif.

\section{d. "Wakaf Uang adalah harta yang diwakafkan oleh wakif dalam bentuk kas yang likuid."}

Menurut penulis, perlu adanya definisi tersendiri mengenai wakaf uang. Karena nazhir penerima dari wakaf ini berbeda dengan nazhir yang menerima harta benda wakaf. Nazhir yang dapat menerima wakaf uang ini adalah nazhir yang merupakan lembaga keuangan Syariah.

\section{e. "Wakif adalah pihak yang mewakafkan harta yang dimiliknya."}

Definisi dari wakif tersebut, penulis adopsi dari Undang-Undang No. 41 Tahun 2004 tentang Wakaf pasal 1 ayat 2 dan buku Pedoman Akuntansi Wakaf. Serta juga berdasarkan dari syarat dan rukun dari wakaf menurut hukum Fiqih.

f. "Ikrar Wakaf adalah pernyataan kehendak wakif yang diucapkan secara lisan dan/atau tulisan kepada Nazhir untuk mewakafkan harta benda miliknya."

Definisi dari ikrar wakaf ini, penulis adopsi dari Undang-Undang No. 41 Tahun 2004 tentang Wakaf pasal 1 ayat 3 dan berdasarkan syarat dan rukun wakaf.

g. "Mauquf 'alaih adalah orang atau entitas yang menerima penyaluran manfaat berdasarkan peruntukkan wakif. "

Definisi tersebut diadopsi dari syarat dan rukun wakaf dan juga berdasarkan buku Pedoman Akuntansi Wakaf. Meskipun di dalam undang-undang tidak ada, namun menurut penulis definisi mengenai mauquf 'alaih itu perlu ada di pernyataan standar akuntansi wakaf. Hal ini karena untuk mengetahui siapa saja yang berhak menerima dari pemanfaatan wakaf.

\section{Pengakuan dan Pengukuran}

Mengacu pada Kerangka Dasar Penyusunan dan Penyajian Laporan Keuangan Syariah menurut AAOIFI, pengakuan terbagi menjadi empat yaitu pengakuan/penghentian aset dan kewajiban, pengakuan pendapatan, pengakuan beban, dan pengakuan untung dan rugi. Namun secara teknis pembagian pengakuan dan pengukuran digabungkan. Pengakuan yaitu hal-hal yang berkaitan dengan apakah suatu transaksi akan dijurnal atau tidak, dan pengukuran adalah menentukan nilai dari suatu transaksi yang telah diakui atau dicatat. Menurut Tanjung dan Ihsan pembagian kelompok dari aset wakaf ini diakui sesuai dengan jenis aset yang diterima.

Untuk pengakuan dan pengukuran di PSAK terbagi menjadi tiga bagian yaitu pengakuan awal, pengukuran setelah pengakuan awal, dan penyaluran. Proses pengakuan ini saling berkaitan dengan pengukuran atas sebuah transaksi. Untuk pengakuan awal, baik itu penerimaan wakaf biasa yang berupa fix asset dan penerimaan cash waqf harus dicatat. Aset yang diterima diakui sebagai penambah aset wakaf. Pada saat penerimaan wakaf uang diakui sebesar nominal yang diwakafkan oleh wakif. Sedangkan penerimaan wakaf biasa yang berupa fix asset, diakui sebesar nilai wajar dari aset tersebut. Menurut Ihsan beliau berpendapat bahwa biasanya dalam praktik pengakuan harta wakaf menggunakan NJOP (Nilai Jual Objek Pajak). Dari setiap penerimaan wakaf yang diterima $10 \%$ akan menjadi milik nazhir, sedangkan 90\%-nya disalurkan sesuai dengan peruntukkan untuk mauquf'alaih. 
Setelah dilakukan pengakuan awal, maka selanjutnya adalah pengukuran setelah pengakuan awal. Untuk wakaf uang, apabila terjadi kerugian atau kehilangan. Itu sepenuhnya akan menjadi tanggung jawab nazhir, karena seperti yang kita ketahui bahwa sifat dari wakaf adalah harus tetap terjaga keasliannya dan memastikan bahwa manfaatnya mengalir sesuai dengan peruntukan wakif. Apabila kerugian atau kesalahan tersebut adalah diakibatkan oleh nazhir. Serta aset wakaf tidak boleh mengikuti distorsi pasar akibat inflasi tertentu (Buku Pedoman Akuntansi Wakaf, 2016).

Pengukuran untuk penyaluran adalah sesuai dengan yang diatur oleh UU No 41 Tahun 2004, sebesar $90 \%$ dari harta yang diwakafkan oleh wakif harus disalurkan. Ketentuan berapa besarnya persentase yang akan disalurkan ke mauquf'alaih secara hukum fiqih pun tidak ada. Seperti pernyataan Mas'udi penyaluran wakaf itu sangat variatif dari setiap nazhir. Hal ini berhubungan dengan kemana fokus program kerja dari nazhir. Jadi tidak ada ketentuan persentase penyaluran seperti zakat, namun prioritasnya tetap untuk pemberdayaan masyarakat yang membutuhkan.

\section{Penyajian}

Penyajian dalam pernyataan standar akuntansi keuangan yaitu menyajikan semua transaksi organisasi atau perusahaan berupa laporan keuangan. Laporan keuangan disajikan agar dapat tergambar segala aktivitas nazhir. Sehingga pengguna laporan keuangan dapat menilai kinerja dari perusahaan dan mengetahui posisi keuangan nazhir.

Jika mengacu pada PSAK 101 mengenai Penyajian Keuangan Syariah, ada delapan laporan keuangan. Namun laporan keuangan untuk nazhir, pastinya tidak mencakup kedelapan laporan tersebut. Karena wakaf berbeda dengan zakat, infak, mapun sedekah. Kalau zakat, infak, dan sedekah harus langsung habis atau harus langsung disalurkan jika sudah diterima. Berbeda dengan wakaf yang harus tetap dijaga keaslian nilainya namun juga harus terus tersalurkan manfaatnya. Sedangkan Jika mengacu pada Buku Pedoman Wakaf (2016) penyajian laporan keuangan terdiri dari lima laporan keuangan yaitu: Laporan Perubahan Dana, Laporan Posisi Keuangan, Laporan Perubahan Aset Kelolaan, Laporan Arus Kas, dan Catatan Atas Laporan Keuangan. Menurut Ihsan, kelima laporan tersebut cukup bisa mengakomodir sifat dari wakaf selagi dapat bersifat informatif. Beliau juga menambahkan bahwa pastinya harus ada laporan aktivitas dari wakaf produktif, laporan arus kas, dan laporan posisi keuangan. Sehingga dapat disimpulkan bahwa laporan keuangan yang harus dibuat oleh lembaga wakaf yaitu Laporan Posisi Keuangan, Laporan Arus Kas, Laporan Perubahan Dana, Laporan Perubahan Aset Kelolaan, Laporan Aktivitas Keuangan, dan Catatan Atas Laporan Keuangan.

\section{Pengungkapan}

Pengungkapan merupakan langkah akhir proses akuntansi dalam menyajikan informasi secara menyeluruh. Tujuan dari pengungkapan adalah menyajikan informasi yang dianggap perlu untuk mencapai tujuan laporan keuangan serta untuk menyediakan informasi untuk berbagai pihak yang memiliki kepentingan berbeda-beda. Menurut PSAK 60 mengenai instrumen keuangan: pengungkapan, hal-hal yang harus diungkapkan dibagi menjadi dua jenis yaitu pengungkapan akuntansi dan pengungkapan resiko. Untuk pengungkapan akuntansi PSAK 60 mensyaratkan bahwa entitas harus mengungkapkan mengenai informasi akuntansi agar pengguna laporan keuangan dapat mengevaluasi signifikansi informasi dari laporan posisi keuangan dan kinerja keuangannya. Sedangkan untuk pengungkapan resiko, PSAK 60 mensyaratkan bahwa entitas harus mengungkapkan informasi agar pengguna laporan keuangan dapat mengevaluasi sifat dan tingkat resiko yang muncul akibat dari instrumen keuangan yang dihadapi entitas pada tanggal pelaporan baik itu informasi kuantitatif maupun informasi kualitatif. Resiko yang dimaksudkan yaitu seperti resiko kredit, resiko likuiditas, resiko pasar, namun hal ini tidak terbatas (Juan \& Wahyuni, 2014). Jika melihat pada PSAK syariah yang ada seperti PSAK 109, pengungkapan yang perlu ada pada catatan atas laporan keuangan entitas antara lain adalah: 
1) Metode penentuan nilai wajar

2) Kebijakan pembagian dana nazhir

3) Kebijakan penyaluran wakaf/ penentuan skala prioritas

4) Keberadaan harta wakaf/ uang wakaf yang tidak disalurkan

5) Hasil/penggunaan dari pengelolaan wakaf produktif

6) Rincian jumlah penyaluran dana (beban dan dana yang diterima langsung)

7) Hubungan Istimewa antara nazhir dan wakif:

a. Sifat hubungan istimewa

b. Jumlah dan jenis aset yang disalurkan

c. Persentase dari aset yang disalurkan tersebut dari total penyaluran selama periode.

d. Keberadaan dana non-halal jika ada

e. Kinerja nazhir atas penerimaan dan penyaluran wakaf

Menurut penulis kesembilan hal diatas dan hal-hal selainnya, apabila itu berkaitan dengan transaksi yang dilakukan oleh nazhir dan memiliki pengaruh pada posisi keuangan perusahaan maka itu harus diungkapkan pada catatan atas laporan keuangan.

\section{Usulan Penyusunan Standar Akuntansi Keuangan Wakaf}

Dalam menyusun standar akuntansi keuangan untuk lembaga wakaf, selain mengacu pada pendapat dari narasumber wawancara peneliti juga mengacu pada beberapa standar keuangan yang telah ada. Standar akuntansi keuangan yang digunakan yaitu KDPPLKS (Kerangka Dasar Penyusunan dan Penyajian Laporan Keuangan Syariah), PSAK 101: Penyajian Laporan Keuangan Syariah, PSAK 109 : Zakat dan Infak/Sedekah, Buku Pedoman Akuntansi Wakaf, AAOIFI, dan Accouting and Reporting by Charities : Statement of Recommended Practice (SORP) 2015. Buku Pedoman Akuntansi Wakaf adalah buku yang dibuat oleh Badan Wakaf Indonesia dengan tujuan sebagai pedoman lembaga wakaf untuk menyusun laporan keuangan. SORP 2015 adalah standar akuntansi keuagan untuk lembaga amal yang dibuat oleh regulator lembaga amal dengan mengacu pada FRS (Financial Reporting Standard) 102 yang diterapkan di Inggris dan Republik Irlandia. Berikut ini adalah beberapa usulan standar akuntansi keuangan wakaf yaitu Laporan Posisi Keuangan, Laporan Arus Kas, Laporan Perubahan Dana, Laporan Perubahan Aset Kelolaan, Laporan Aktivitas Keuangan, dan Catatan Atas Laporan Keuangan.

\section{KETERBATASAN PENELITIAN}

Penelitian ini hanya menggunakan data dari delapan narasumber. Hal ini memungkinkan kurang sempurnanya data yang diperoleh. Penelitian ini juga kurang didukung dengan adanya penyebaran kuesioner mengenai urgensi dari PSAK Wakaf ke seluruh lembaga wakaf yang ada di Indonesia, dikarenakan keterbatasan waktu dan biaya. Serta kurangnya observasi langsung atau studi kasus mengenai masalah-masalah apa saja yang menjadi hambatan dalam penyusunan laporan keuangan oleh lembaga sehingga diperlukan adanya standar. Penelitian ini hanya menggunakan tiga variabel independen, sedangkan masih ada variabel-variabel independen lain yang berpengaruh terhadap kebijakan hutang.

\section{KESIMPULAN}

Berdasarkan hasil penelitian dapat disimpulkan bahwa saat ini PSAK Wakaf sangat diperlukan. Diharapkan dengan adanya PSAK Wakaf dapat menyeragamkan praktik akuntansi lembaga wakaf dan mengakomodir karakteritik dari wakaf yang belum bisa diakomodir oleh standar akuntansi yang digunakan selama ini. Suatu standar akuntansi keuangan yang akan digunakan sebagai pedoman berupa PSAK maka harus memenuhi beberapa hal yaitu definisi, pengukuran/penilaian, 
pengakuan, penyajian, dan pengungkapan. Agar dapat menyeragamkan laporan keuangan lembaga wakaf, berikut ini adalah beberapa usulan standar akuntansi keuangan wakaf yaitu Laporan Posisi Keuangan, Laporan Arus Kas, Laporan Perubahan Dana, Laporan Perubahan Aset Kelolaan, Laporan Aktivitas Keuangan, dan Catatan Atas Laporan Keuangan.

Penelitian selanjutnya diharapkan memperoleh data dari beberapa narasumber lain yang lebih banyak seperti dari IAI, praktisi-praktisi wakaf, wakif dan pajak. Penelitian selanjutnya pun diharapkan bisa menyebarkan kuesioner mengenai urgensi dari PSAK Wakaf ke seluruh lembaga wakaf di Indonesia, serta dapat melakukan Focus Group Discussion dengan berbagai pihak yang relevan dengan penelitian seperti IAI, BWI, akademisi, praktisi, nazhir dan pajak. Serta dapat melakukan observasi dan studi kasus masalah atau hambatan lembaga dalam menyusun laporan keuangan wakaf.

\section{LAMPIRAN}

Lampiran 1 Laporan Posisi Keuangan

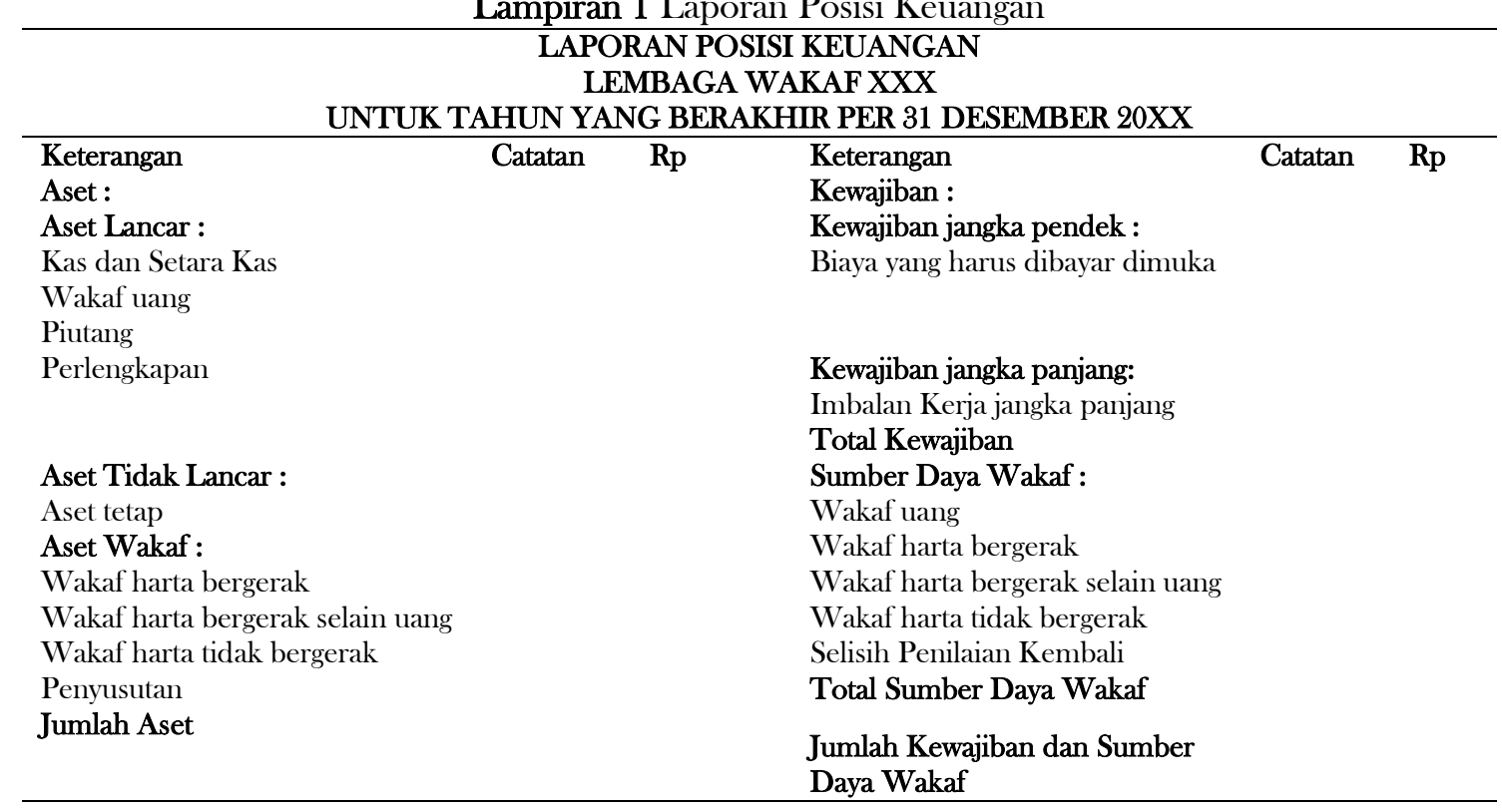

Lampiran 2 Laporan Arus Kas LAPORAN ARUS KAS

LEMBAGA WAKAF XXX

UNTUK TAHUN YANG BERAKHIR PER 31 DESEMBER 20XX

Keterangan
Arus Kas dari Aktivitas Operasi

Catatan Rp

Pemasukan :

Penerimaan wakaf uang

Penerimaan dana nazhir

Penerimaan Wakaf produktif

Pengeluaran :

Penyaluran dana nazhir

Penyaluran dana APBN

Arus Kas bersih dari (untuk) Aktivitas Operasi

Arus Kas dari Aktivitas Investasi

Pemasukan :

Deposito

Pengeluaran :

Pembelian Peralatan

Arus Kas bersih dari (untuk) Aktivitas Investasi

Arus Kas dari Aktivitas Pendanaan 


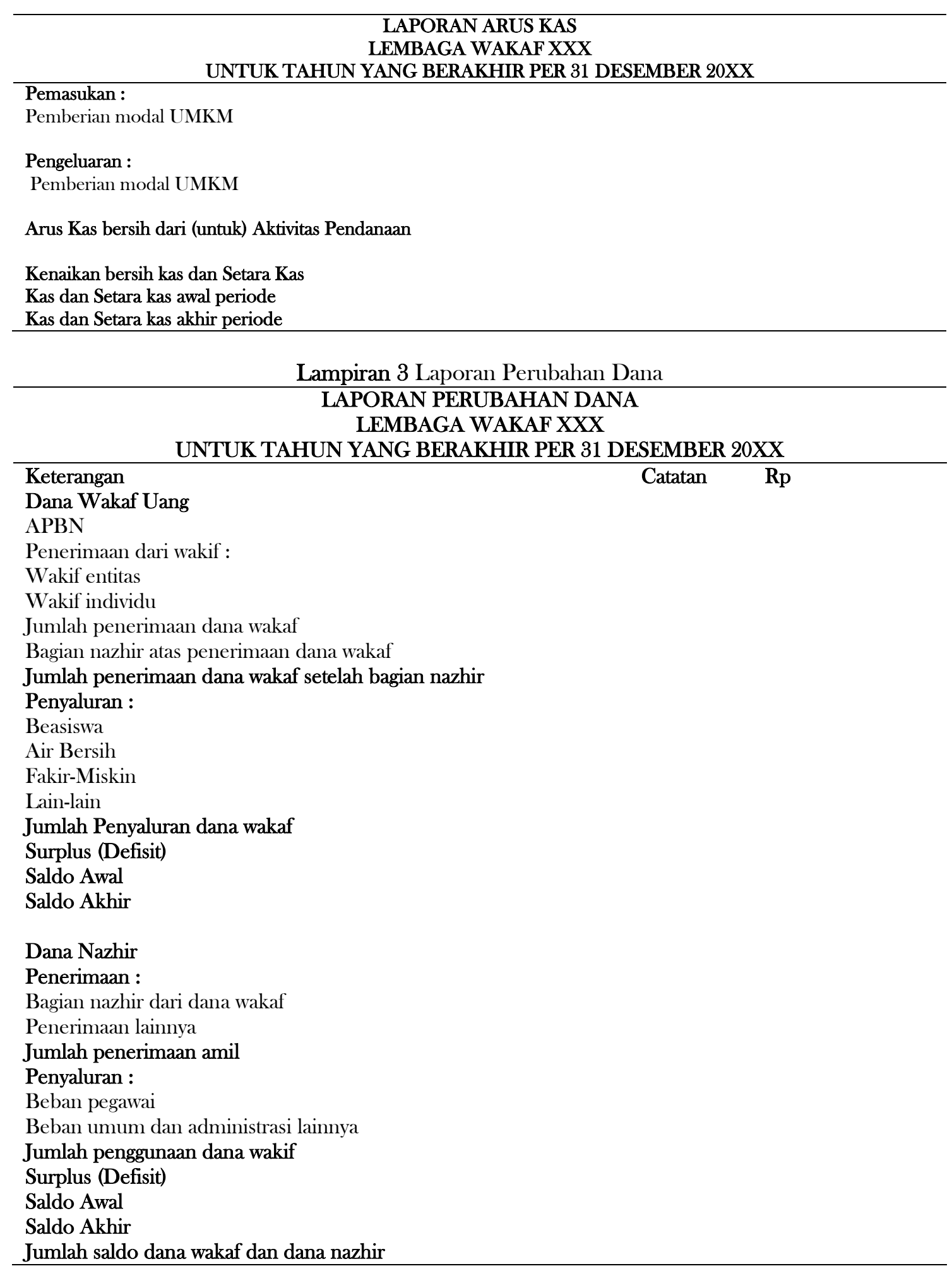


Lampiran 4 Laporan Perubahan Aset Kelolaan

\section{LAPORAN PERUBAHAN ASET KELOLAAN}

LEMBAGA WAKAF XXX

UNTUK TAHUN YANG BERAKHIR PER 31 DESEMBER 20XX

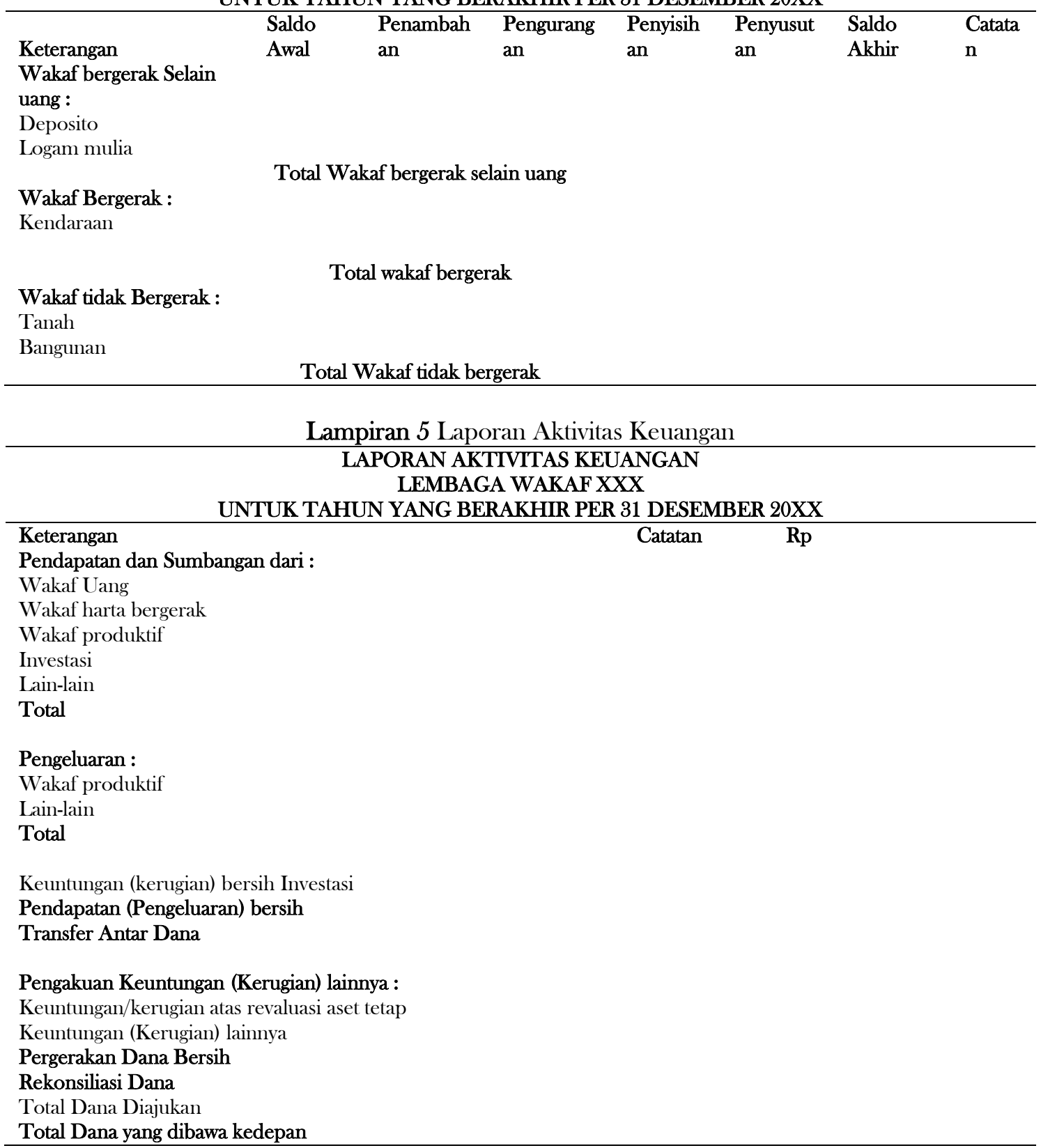

\section{DAFTAR PUSTAKA}

Adnan, M. A., \& Ihsan, H. (2009). Waqf Accounting and Construction of Accountability. International Conference in Waqf Laws and Management: Reality Propects. Kuala Lumpur. Adnan, M. A., Sulaiman, M., \& Nor, P. N. (2007). Some Thought About Accounting Conceptual Framework and Standards for Awqaf Institution. Indonesian management and Accounting Research Vol. 6 No.1, 43-56.

Budiman, A. A. (2011). Akuntabilitas Lembaga pengelola Wakaf. Walisongo, 94-95.

BWI. (2016). Pedoman Akuntansi Wakaf. Jakarta. 
Ihsan, H., Sulaiman, M., Alwi, N. M., \& Adnan, M. A. (2016). Waqf Accountability from The Stakeholder Salience Theory: A Case Study. Journal of Islamic Monetary Economics and Finance Vol. 2, No. 1, 1-40.

Ihsan, H., Sulaiman, M., Alwi, N. M., \& Adnan, M. A. (2017). A Study of Accountability Practice in Dompet Dhuafa in Indonesia. JKAU: Islamic Econ Vol. 30 No. 2, 13-32.

Juan, N. E., \& Wahyuni, T. E. (2014). Panduan Praktis Standar Akuntansi Keuangan. Jakarta: Salemba Empat.

Masruki, R., \& Shafii, Z. (2013). The Development of Waqf Accounting in Enhancing Accountability. Middle-East Journal of Scientific Research, 1-6.

Mazaya (Ed.). (2017, November 9). Jurnalislam.com. Retrieved Januari 23, 2018, from https:/jurnalislam.com/tingkatkan-tata-kelola-wakaf-bwi-gelar-seminar-internasionalmembahas-waqf-core-principles/.

Muhsan. (2013). Wakaf di Saudi Arabia dan Mesir (Tinjauan Manajemen dan Terapan Wakaf Produktif). Jurnal Dirasat Islamiyah Volume 1 No 1, 151-155.

Nurhayati, S., \& Wasilah. (2015). Akuntansi Syariah di Indonesia. Jakarta: Salemba Empat.

PSAK 109 Akuntansi Zakat dan Infak/Sedekah, Ikatan Akuntan Indonesia, diakses 31 Januari 2018 pukul 13:59

Regulator, O. o. (2015). Charities SORP (FRS 102). Retrieved Juli 28 pukul 10:41, 2017

Rozalinda. (2010, Mei 4). www.rozalinda.wordpress.com. Retrieved Oktober 24, 2017, from https://rozalinda.wordpress.com/2010/05/04/perkembangan-perwakafan-di-indonesia/

Rozalinda. (2015). Manajemen Wakaf Produktif. Jakarta: Rajawali Pers.

Setiabudi, H. Y., \& Triyuwono, I. (2002). Akuntansi Ekuitas. Jakarta: Salemba Empat.

SIMBI. (2016). www.kemenag.go.id. (D. P. Wakaf, Producer) Retrieved Oktober 26, 2017, from www.simbi.kemenag.go.id:

http://simbi.kemenag.go.id/pustaka/images/materibuku/Fiqih\%20Wakaf-2006.pdf

Sugiyono. (2005). Memahami penelitian Kualitatif. Bandung: Alfabeta.

Sugiyono. (2014). Metode Penelitian Bisnis (Pendekatan Kuantitatif, Pendekatan Kualitatif, dan $R \& D)$. Bandung: Alfabeta.

Sujarweni, V. W. (2014). Metodologi Penelitian. Yogyakarta: PT. Pustaka Baru.

Suparman, \& Nizar, A. (2009, Januari 27). Gagasan Penyusunan Laporan Keuangan Bagi Nazhir Profesional. Retrieved Agustus 3, 2017, from Badan Wakaf Indonesia: http://www.bwi.or.id

Suwardjono. (2014). Teori Akuntansi Perekayasaan Pelaporan Keuangan. Yogyakarta: BPFE.

Yaacob, H., Petra, S., Sumardi, A., \& Nahar, H. S. (2012). Awqaf Accounting and Reporting for Accountability: A Case Study of Awqaf S. SSRN.

Yusuf, M. (2015). Metode Penelitian: Kuantitatif, Kualitatif, dan Penelitian Gabungan. Jakarta: Prenadamedia Group.

Zakaria, M., Hassan, M. S., \& Latiff, R. A. (2014). Pelaporan Wakaf di Malaysia: Mengenalpasti Keperluan Maklumat Pemegang Kepentingan. Persidangan Kebangsaan Ekonomi Malaysia ke-9 (PERKEM ke-9), Terengganu. 